\title{
TECHNICAL BASES FOR THE SALT PROCESSING CELL DILUTION STRATEGY FOR THE LOW NITRITE PROCESS (U)
}

by S. R. Young

Westinghouse Savannah River Company Savannah River Site,

Aiken, South Carolina 29808

Other Authors:
WSRC-TR--92-481

DE93 006872

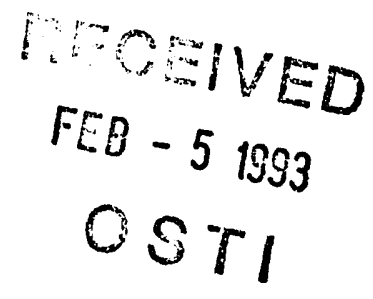

This paper was prepared in connection with work done under Contract No. DE-AC09-89SR18035 with the U. S. Department of Energy. By acceptance of this paper, the publisher and/or recipient acknowledges the U.S. Government's right to retain a nonexclusive, royaliy-free license in and to any copyright covering this paper, along with the right to reproduce and to authorize others to reproduce all or part of the copyrighted paper. 


\section{DISCLAIMER}

This report was prepared as an account of work sponsored by an agency of the United States Government. Neither the United States Government nor any agency thereof, nor any of their employees, makes any warranty, express or implied, or assumes any legal liability or responsibility for the accuracy, completeness, or usefulness of any information, apparatus, product, or process disclosed, or represents that its use would not infringe privately owned rights. Reference herein to any specific commercial product, process, or service by trade name, trademark, manufacturer, or otherwise does not necessarily constitute or imply its endorsement, recommendation, or favoring by the United States Government or any agency thereof. The views and opinions of authors expressed herein do not necessarily state or reflect those of the United States Government or any agency thereof.

This report has been reproduced directly from the best available copy.

Available to DOE and DOE contractors from the Office of Scientific and Technical Information, P. O. Box 62, Oak Ridge, TN 37831; prices available from (615) $576-8401$.

Available to the public from the National Technical Information Service, U. S. Department of Commerce, 5285 Port Royal Rd., Springfield, VA 22161. 


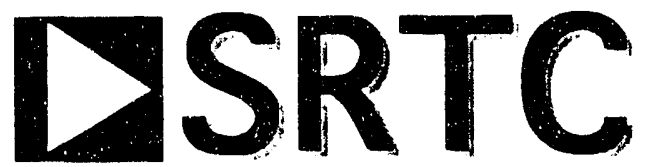

Savannah River Technology Center

WASTE MANAGEMENT AND ENIVIRONMENTAL TECHNOLOGY

Keywords: DWPF, Salt Process Cell, ?recipitate Reactor, Flammability, Carbon Dioxide

Distribution: see last page

Publication Date: October 22, 1992

TO: E. W. Holtzscheiter, 773-A

FROM: S. R. Young, 704-1T

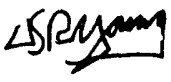

TECHNICAL BASES FOR THE SALT PROCESS CELL DILUTION STRATEGY FOR THE LOW NITRITE PROCESS (U)

\section{Summary}

This document recommends an interim dilution strategy for the low nitrite precipitate hydrolysis process. A minimum carbon dioxide purge rate of $27 \mathrm{scfm}$ during feeding and for 15 minutes after feeding and a maximum precipitate slurry feed rate of $36 \mathrm{gpm}$ are recommended. These recommendations provide an interim dilution strategy that will provide for the start of cold chemical runs and until additional offgas data is collected from the PHEF (Precipitate Hydrolysis Experimental Facility).

The recommended strategy assumes all of the nitrite fed is converted to nitric oxide and all of the nitric oxide is oxidized to nitrogen dioxide. This approach is considered to be highly conservative since (1) the generation of neither nitric oxide nor nitrogen dioxide has been confirmed and (2) nitrogen balances from PHEF low nitrite demonstrations indicate that a large portion of the nitrite is consumed by reactions that produce nitrogen containing organic compounds. Hardware changes are not required since implementation of this strategy does not require measurement of either nitric oxide or nitrogen dioxide. After the low nitrite process offgas is characterized at the PHEF, a more efficient approach will likely be recommended to replace the interim strategy. 
A roved by

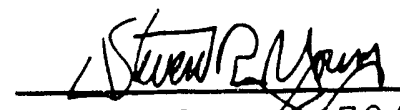

S.R. Younes, 704-1T

Author

Large Scale Experimentation Group

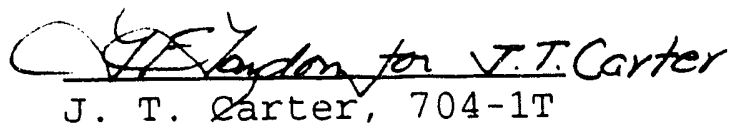

Manager

Large Scale Experimentation Group

Ew bloct pukuten 19/25/92

E. W. Holtzscheiter, 773-A

Manager

Defense Waste Processing Technology

Peer Reviewed by

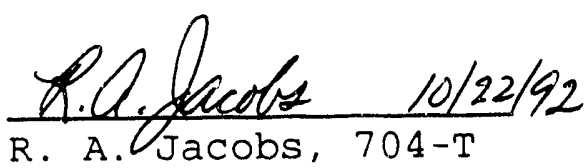

Process Technology Development Group

\section{Drafts Reviewed by}

J. T. Carter

L. F. Landon

R. E. Edwards

D. P. Lambert

H. B. Shah

R. A. Jacobs

J. C. Marek

C. J. Bannochie

\section{Authorized Derivative Classifier}

EW Abetprehuter 


\section{Introduction}

oxygen, nitric oxide and nitrogen dioxide are considered to be potential oxidants for the low nitrite precipitate hydrolysis flow sheet. Benzene, as in the HAN precipitate hydrolysis process, is the fuel. The source of oxygen is air inleakage. The postulated source of nitric oxide is the reaction of formic acid with nitrite.

$$
2 \mathrm{NaNO}_{2}+3 \mathrm{HCOOH}=2 \mathrm{NaCOOH}+2 \mathrm{NO}+2 \mathrm{H}_{2} \mathrm{O}+\mathrm{CO}_{2}
$$

This reaction was postulated in the technical data summary from 1985. 11) Because of the oxygen from air inleakage, there is a potential for formation of nitrogen dioxide from the reaction of nitric oxide with oxygen.

$$
2 \mathrm{NO}+\mathrm{O}_{2}=2 \mathrm{NO}_{2}
$$

The known minimum oxidant concentrations (MOC) for combustion of these three oxidants are listed in Table 1 and the tecnary fuel/oxidant/diluent diagrams with the flammable mixture envelopes for $\mathrm{NO}$ and $\mathrm{NO}_{2}$ are attached. $[2,3]$ Note that the MOCs of nitric oxide and nitrogen dioxide are for nitrogen as the diluent, not carbon dioxide. The MOCs with nitrogen as the diluent will be used, since (1) data for carbon dioxide is not available and (2) the Mocs based on nitrogen are conservative compared to those based on carbon dioxide. This conservativeness is exemplified in Table 2, where the MOCs for two oxidants (air and nitrous oxide) with both diluents (nitrogen and carbon dioxide) are compared. Carbon dioxide is more effective than nitrcgen for inerting because of its higher molar heat capacity. An inert gas prevents ignition primarily by absorbing heat of reaction and preventing the mixture from reaching a temperature that is self-sustaining. (3)

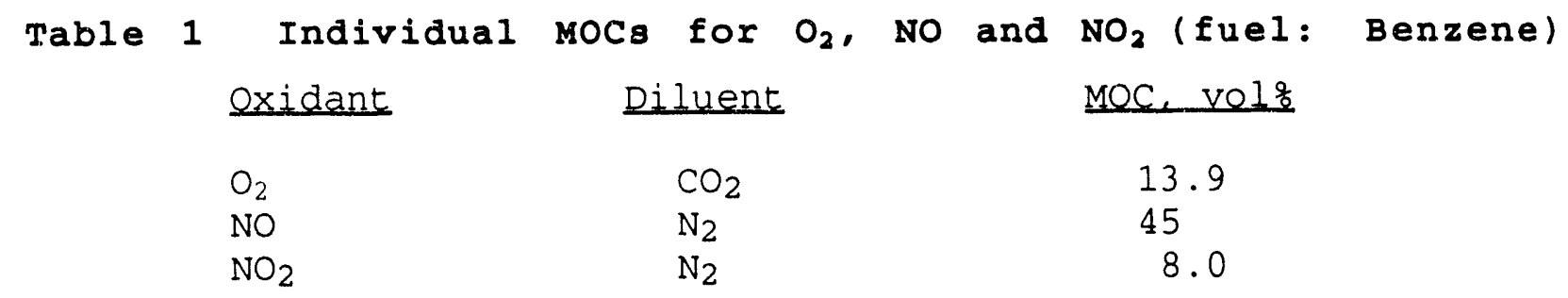

Table 2 MOCs for $\mathrm{CO}_{2}$ vs $\mathrm{N}_{2}$ as Diluent (fuel: Benzene) $(2,3)$ oxidant MOC with N2 Mioc with $\mathrm{CO} 2$

$\begin{array}{lll}\mathrm{O} 2 & 11.2 & 13.9 \\ \mathrm{~N} 2 \mathrm{O} & 21.3 & 29.4\end{array}$




\section{Dilution strategy}

A Combustion Engineering gas chromatograph was used to monitor for nitric oxide during PHEF runs 60-63 (low nitrite flow sheet demonstrations). The process sample was pulled downstream of the Vent Condenser (VC) near the vessel vent control valve. Nitric oxide was not detected at any point during these runs. (4) Unfortunately, this does not preclude the generation of nitric oxide, since any nitric oxide generated could have been oxidized to nitrogen dioxide before reaching the analyzer. Installation of a mass spectrometer, capable of measuring both nitric oxide and nitrogen dioxide, is underway. Since the nitric oxide and nitrogen dioxide have not been measured directly, all of the nitrite will be assumed to be converted to nitrogen dioxide.

In the HAN flow sheet, the total oxidant concentration was approximated to be proportional to the feed flow rate, which was justified since nitrous oxide was the predominant oxidant at the nominal feed rate. This approximation provided an easy means to set the target purge rate based on the feed nitrite concentration and feed rate. For the low nitrite flow sheet, much less oxidant (nitric oxide and nitrogen dioxide, or $\mathrm{NO}_{x}$ ) is expected to be generated relative to oxygen, as compared to the HAN flow sheet. The dominant oxidant for the low nitrite flow sheet is uncertain, since there is little data on $\mathrm{NO}_{x}$ generation and since air inleakage flow rates are relatively unconstrained. While there is an interlock for oxygen concentration at $60 \%$ of the MOC for a benzene/air/carbon dioxide system, there is not a practical air inleakage flow rate maximum useful for flammability control. The available data does not justify approximating the total oxidant concentration and the required carbon dioxide purge to be proportional to the feed rate.

The strategy presented here recommends a target and limit for the feed rate and the carbon dioxide flow rate to the PR during feeding. While this strategy is not as flexible as the HAN dilution strategy, this strategy is an interim solution for cold chemical runs, where the nitrite concentration will be relatively constant. Two software linits are recommended: one for the maximum feed rate and another for the minimum carbon dioxide purge rate. The maximum feed rate is $120 \%$ of the suggested target feed rate, which should allow for normal fluctuations in the feed rate. Similarly, the minimum purge rate is $80 \%$ of the suggested target purge rate. If control within these limits is difficult, the target feed rate can be decreased and the target purge rate increased, to provide larger margins for deviation.

Since the recommended purge rate is considerably larger than expected baseline purge rates, the baseline purge rates were neglected in the supporting calculations. The baseline purge, in addition to other neglected components (e.g. benzene and water), will only dilute the offgas more than predicted.

The baseline purge rates, as in the HAN process, are required to dilute oxygen from air inleakage. As prescribed by DWPF process 
requirements, the baseline purge rates should dilute oxygen from air inleakage to less than $60 \%$ of the MOC for a benzene/air/carbon dioxide mixture.

\section{Guidelines}

The goal of the strategy is to reduce the possibility of forming a flammable mixture in the SPC vessel vent system, in the event that $\mathrm{NO}_{x}$ is generated during feeding. This goal is achieved by applying principles of the National Fire Protection Association. The National Fire Protection Association (NFPA) recommends the following (5):

"Where the [oxidant] concentration is not continuously monitored, the [oxidant] concentration shall be designed to operate at no more than 60 percent of the [MOC], or 40 percent of the [MOC] if the [MOC] is below 5 percent."

Because the NFPA guidelines are general, "oxidant" has been substituted for "Oxygen" and "MOC" has been substituted for "IOC" (Limiting oxidant concentration) in the above quoted text. The above NFPA guideline reduces the possibility of forming a flammable mixture by maintaining a safety margin between the nermal oxidant concentration and the MOC:

"A safety margin shall be maintained between the [MOC] and the normal working concentration in the system."

While normal air inleakage rates are expected to be relatively low, there is not a practical air inleakage flow rate maximum useful for flammability control. In the event that abnormally high inleakage rates occur during feeding, the minimum purge rate should dilute the total oxidant concentration such that a flammable mixture is not formed. The design basis air inleakage rates will be used for normal conditions. The guidelines applied to the recommended dilution strategy are summarized below:

\section{The normally expected total oxidant concentration shall} not exceed $60 \%$ of the MOC.

\section{A flammable mixture shall be prevented in ine event of abnormally high inleakage rates.}

Guideline 1 shall be satisfied by placing controls on the feed rate, purge rate and the precipitate slurry simulant feed nitrite concentration. Guideline 2 shall be satisfied by using the controls established for guideline 1 and the oxygen concentration interlock $\left(60 \%\right.$ of 13.9 vol\% $\mathrm{O}_{2}=8.4$ vol\% $\left.\mathrm{O}_{2}\right)$. As demonstrated for the HAN process[6], the oxygen concentration will reach 8.4 volo before a flammable mixture is formed.

The worst case mixture within the SPC vessel vent system is expected to be downstream of the SCVC inlet, since oxygen from the PRFT, OE 
and OECT will combine with the PR offgas at the SCVC inlet. While the total oxidant concentration decreases as a result of the nitric oxide oxidation, the composite MOC decreases by a larger percent (because of the large disparity between the nitric oxide and nitrogen dioxide MOCs).

\section{Bases For Calculations}

The bases for the dilution strategy are listed below. These bases represent normal conditions.

1. The maximum feed rate of precipitate slurry is 36 gals/min. The recommended target feed rate is 30 gals/min, which is equivalent to the feed rates used during the PHEF demonstrations and bench-scale studies. The maximum feed rate, $36 \mathrm{gal} / \mathrm{min}$, is $120 \%$ of the recommended target, $30 \mathrm{gals} / \mathrm{min}$.

2. The maximum precipitate slurry soluble nitrite concentration is $0.01 \mathrm{M}$. The soluble nitrite concentration for chemical runs and radioactive operation is specified as $\leq$ $0.01 \mathrm{M}$.

Note: all calculations used the precipitate slurry insoluble solids concentration and density specified for cold chemical runs to convert from soluble to slurry concentration ( 8.7 wt insoluble solids and a specific gravity of 1.2). (7)

3. All of the nitrite fed is converted to nitric oxide via reaction (1).

4. All of the nitric oxide is oxidized to nitrogen dioxide via reaction (2), provided the stoichiometric oxygen requirement is satisfied lone mole of $\mathrm{O}_{2}$ per mole of NO).

5. The air inleakage rate is $1.5 \mathrm{lb}$ air/hr/vessel, which is the design bases rate.

6. The composite MOC is determined using le chatiler's rule. Le Chatlier's rule was also applied to the dilution strategy for the HAN Precipitate Hydrolysis Process. [8] Le Chatlier's rule applied to the composite MOC (MOC comp) for $n$ oxidants is:

$\mathrm{MOC}_{\text {comp }}=\frac{100}{\mathrm{C}_{1} / \mathrm{M}_{1}+\mathrm{C}_{2} / \mathrm{M}_{2}+\cdots \mathrm{C}_{\mathrm{n}} / \mathrm{M}_{\mathrm{n}}}$

Where $C_{n}=$ concentration of oxidant $n$ as percent of total oxidants $\left(\frac{\%}{8}\right)$

$\mathrm{M}_{\mathrm{n}}=$ MOC fr:r oxidant $\mathrm{n}$ (vol\%)

7. All reactions are instantaneous. 
Four scenarios were evaluated using the bases outlined above. These scenarios demonstrate the need for the recommended purge rate and demonstrate that the recommended dilution strategy satisfies both of the guidelines introduced above. Each scenario is summarized by a table that includes composition, flow rates, oxygen concentration, total oxidant concentration and the composite MOC for both before and after nitric oxide is oxidized to nitric oxide.

Initially, the carbon dioxide purge rate required to dilute the total oxidant concentration below $60 \%$ of the composite MOC was determined for design basis air inleakage rates. As indicated in Table 3 , a carbon dioxide purge rate of $11 \mathrm{scfm}$ will dilute the tctal oxidant concentration below $60 \%$ of the composite MOC for design basis air inleakage rates. This purge rate, however, would not be sufficient in the event of above normal inleakage rates. Table 4 summarizes the scenario where the carbon dioxide purge rate is $11 \mathrm{scfm}$ and high air inleakage rates cause the oxygen concentration to reach the interlock level $\left(8.4\right.$ vol\% $\left.\mathrm{O}_{2}\right)$. Since the total oxidant concentration exceeds the composite MOC, $11 \mathrm{scfm}$ is insufficient.

A carbon dioxide purge rate of 27 scfm was determined to satisfy both guidelines (see Guidelines). A total oxidant concentration equal to $85 \%$ of the composite MOC was selected to satisfy guideline 2 . Table 5 evaluates the offgas with 27 scfm carbon dioxide for design basis air inleakage and Table 6 evaluates 27 scfm carbon dioxide for the above normal air inleakage scenario. For normal condicions (Table 5), the oxidant concentration is well below $60 \%$ of the MOC and for high air inleakage (Table 6), the oxidant concentration is significantly below the MOC when the oxygen concentration reaches 8.4 vol\%.

rwo additional scenarios were evaluated to demonstrate the conservativeness of the recommended strategy. The two scenarios, which are illustrated in Tables 7 and 8 , use data from PHEF nitrogen balances that indicate two-thirds of the nitrite fed is converted to nitrogen containing organic compounds (i.e. n-phenylformamide, aniline, diphenylamine, nitrosoberzene, and nitrobenzene)(4). When only one-third of the nitrite fed is converted to nitric oxide and the nitric oxide is completely oxidized and the air inleakage rate is maximized such that the oxygen concentration is at the interlock, the total oxidant concentration will be $69 \%$ of the composite MOC. The most likely scenario (of those presented) is that only one-third of the nitrite fed is converted to nitric oxide and the nitric oxide is completely oxidized and the air inleakage rate is at the design basis. In this case, the total oxidant concentration is expected to be only $17 \%$ of the composite MOC.

The recommended dilution strategy for the $P R$ during feeding and for 15 minutes after feeding is summarized in Table 9. 
Table 3 Design Basis Inleakage with 11 scfm $\mathrm{CO}_{2}$

\begin{tabular}{|c|c|c|c|c|}
\hline $\begin{array}{l}\text { Basod / Paramotora } \\
\text { Parameter }\end{array}$ & Value & Unit & & \\
\hline NO generated/Nitrite Fed & 1.00 & $\mathrm{~mol} / \mathrm{mol}$ & & \\
\hline NO2 generated/NO generated & 1.00 & $\mathrm{~mol} / \mathrm{mol}$ & & \\
\hline Air leakage per vessel & 1.50 & $\mathrm{lb} / \mathrm{h}$ & & \\
\hline Feed rate & 2160 & gph & 36 & gpm) \\
\hline Feed nitrite concentration & 0.0100 & M (soluble) & & \\
\hline $\mathrm{CO} 2$ flow rate & 11 & $\operatorname{scfm}$ & & \\
\hline
\end{tabular}

\begin{tabular}{|c|c|c|c|c|c|}
\hline $\begin{array}{l}\text { Plow Rat } \\
\text { Before No } \\
\text { Component }\end{array}$ & $\begin{array}{r}\begin{array}{r}\text { comp } \\
\text { dation }\end{array} \\
\mathrm{lb} / \mathrm{h}\end{array}$ & $1 \mathrm{bmol} / \mathrm{h}$ & $\operatorname{scfm}$ & $\begin{array}{l}\text { volz } \\
\text { (of total) }\end{array}$ & $\begin{array}{l}\text { vol g } \\
\text { (of oxidant) }\end{array}$ \\
\hline $\mathrm{CO} 2$ & 80.89 & 1.84 & 11.00 & 83.05 & \\
\hline 02 & 1.39 & 0.04 & 0.26 & 1.97 & 20.58 \\
\hline $\mathrm{N} 2$ & 4.58 & 0.16 & 0.92 & 7.39 & \\
\hline No & 5.04 & 0.17 & 1.00 & 7.59 & 79.42 \\
\hline $\mathrm{NO} 2$ & 0.00 & 0.00 & 0.00 & 0.00 & 0.00 \\
\hline Air & 6.00 & 0.21 & 1.24 & 9.36 & \\
\hline oxidant & 6.43 & 0.21 & 1.26 & 9.55 & 100.00 \\
\hline Total. & 91.90 & 2.21 & 13.24 & 100.00 & \\
\hline \multicolumn{2}{|c|}{ s) of Composite MOC } & $\begin{array}{l}30.8 \\
31.0\end{array}$ & & & \\
\hline
\end{tabular}

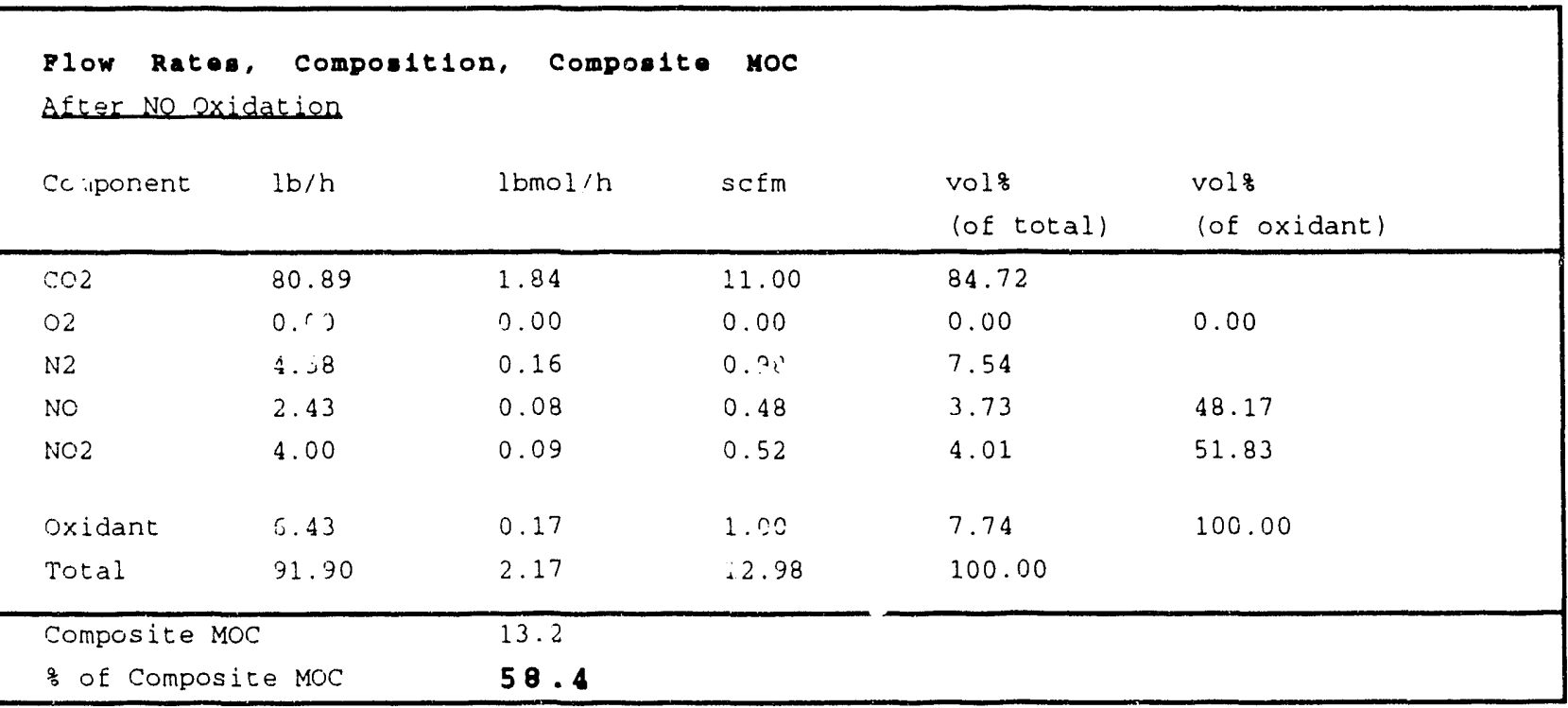


Táble 4 Above Normal Air Inleakage With 11 acfm $\mathrm{CO}_{2}$

\begin{tabular}{|c|c|c|c|c|}
\hline $\begin{array}{l}\text { Bases / Parametora } \\
\text { Parameter }\end{array}$ & Value & Unit & & \\
\hline No generated/Nitrite Fed & 1.00 & $\mathrm{~mol} / \mathrm{mol}$ & & \\
\hline $\mathrm{NO} 2$ generated/NO generated & 1.00 & $\mathrm{~mol} / \mathrm{mol}$ & & \\
\hline Air leakage per vessel & 14.10 & $1 \mathrm{~b} / \mathrm{h}$ & & \\
\hline Feed rate & 2160 & gph & 36 & gpm) \\
\hline Feed nitrite concentration & 0.0100 & M (soluble) & & \\
\hline CO2 Elow rate & 11 & $\operatorname{scfm}$ & & \\
\hline
\end{tabular}

\begin{tabular}{|c|c|c|c|c|c|}
\hline $\begin{array}{l}\text { Plow Rat } \\
\text { Befere Ne } \\
\text { Component }\end{array}$ & $\begin{array}{l}\text { Compo } \\
\text { dation } \\
1 \mathrm{~b} / \mathrm{h}\end{array}$ & $1 \mathrm{bmol} / \mathrm{h}$ & scfm & $\begin{array}{l}\text { vols } \\
\text { (of total) }\end{array}$ & $\begin{array}{l}\text { vol\% } \\
\text { (of oxidant) }\end{array}$ \\
\hline $\mathrm{CO} 2$ & 80.89 & 1.84 & 11.00 & 46.50 & \\
\hline 02 & 13.09 & 0.41 & 2.45 & 10.34 & 70.89 \\
\hline N2 & 43.08 & 1.54 & 9.21 & 38.91 & \\
\hline NO & 5.04 & 0.17 & 1.00 & 4.25 & 29.11 \\
\hline $\mathrm{NO} 2$ & 0.00 & 0.00 & 0.00 & 0.00 & 0.00 \\
\hline Air & 56.40 & 1.95 & 11.65 & 49.26 & \\
\hline oxidant & 18.12 & 0.58 & 3.45 & 14.59 & 100.00 \\
\hline Total & 142.09 & 3.95 & 23.66 & 100.00 & \\
\hline $\begin{array}{l}\text { Composite } \\
s_{;} \text {of Comp }\end{array}$ & e MOC & $\begin{array}{l}17.4 \\
83.9\end{array}$ & & & \\
\hline
\end{tabular}

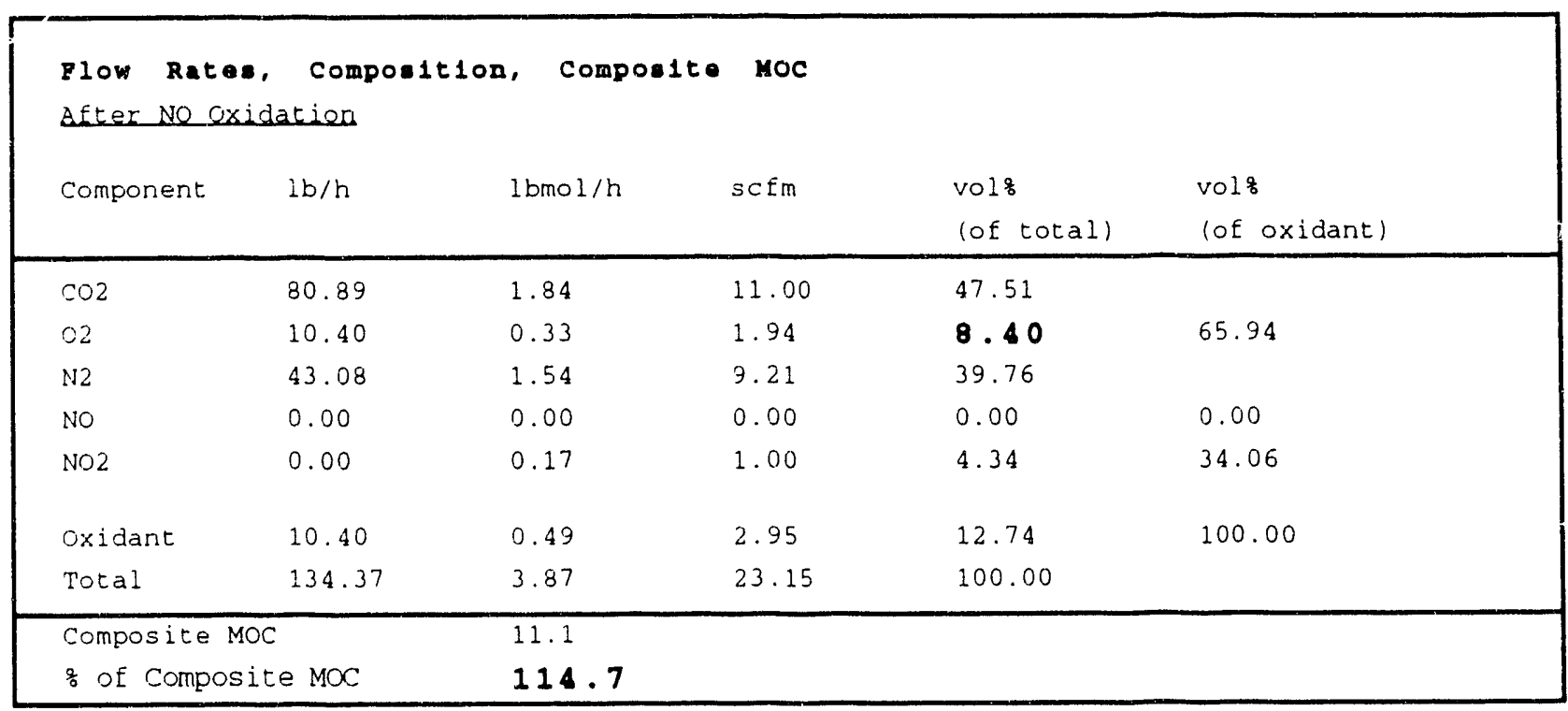


Table 5 Design Basis Air Inleakage with 27 scfm $\mathrm{CO}_{2}$

\begin{tabular}{|c|c|c|c|c|}
\hline $\begin{array}{l}\text { Bases / Parametera } \\
\text { Parameter }\end{array}$ & Value & Unit & & \\
\hline No generated/Nitrite Fed & 1.00 & $\mathrm{~mol} / \mathrm{mol}$ & & \\
\hline NO2 generated/NO generated & 1.00 & $\mathrm{~mol} / \mathrm{mol}$ & & \\
\hline Air leakage per vessel & 1.50 & $1 b / h$ & & \\
\hline Feed rate & 2160 & gph & 36 & gpm) \\
\hline Feed nitrite concentration & 0.0100 & M (soluble) & & \\
\hline CO2 flow rate & 27 & $\operatorname{scfm}$ & & \\
\hline
\end{tabular}

\begin{tabular}{|c|c|c|c|c|c|}
\hline $\begin{array}{l}\text { Plow Rat } \\
\text { Befous No } \\
\text { Component }\end{array}$ & $\begin{array}{c}\text { Compc } \\
\text { dation } \\
1 \mathrm{~b} / \mathrm{h}\end{array}$ & \multicolumn{2}{|c|}{ Composite MOC } & volo & $\begin{array}{l}\text { volz } \\
\text { (of oxidant) }\end{array}$ \\
\hline $\mathrm{CO} 2$ & 198.55 & 4.51 & 27.00 & 92.33 & \\
\hline 02 & 1.39 & 0.04 & 0.26 & 0.89 & 20.58 \\
\hline $\mathrm{N} 2$ & $\because 58$ & 0.16 & 0.98 & 3.35 & \\
\hline No & 5.04 & 0.17 & 1.00 & 3.44 & 79.42 \\
\hline NO2 & 0.00 & 0.00 & 0.00 & 0.00 & 0.00 \\
\hline Air & 6.00 & 0.21 & 1.24 & 4.24 & \\
\hline Oxiclant & 6.43 & 0.21 & 1.26 & 4.33 & 100.00 \\
\hline Total & 209.56 & 4.89 & 29.24 & 100.00 & \\
\hline $\begin{array}{l}\text { Composite } \\
: \text { of Comp }\end{array}$ & Composite MOC & $\begin{array}{l}30.8 \\
14.0\end{array}$ & & & \\
\hline
\end{tabular}

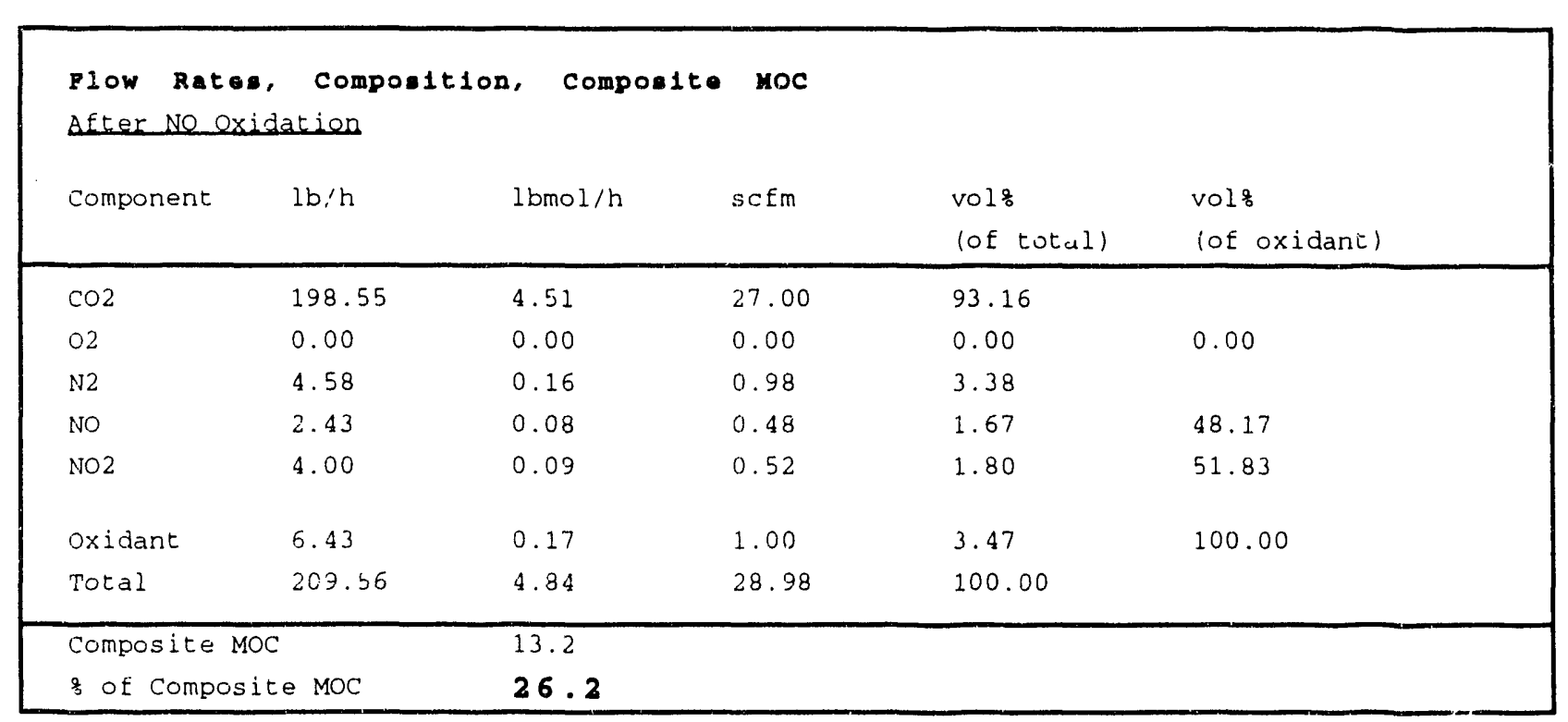




\section{Table 6 High Air Inleakage with 27 scfm $\mathrm{CO}_{2}$}

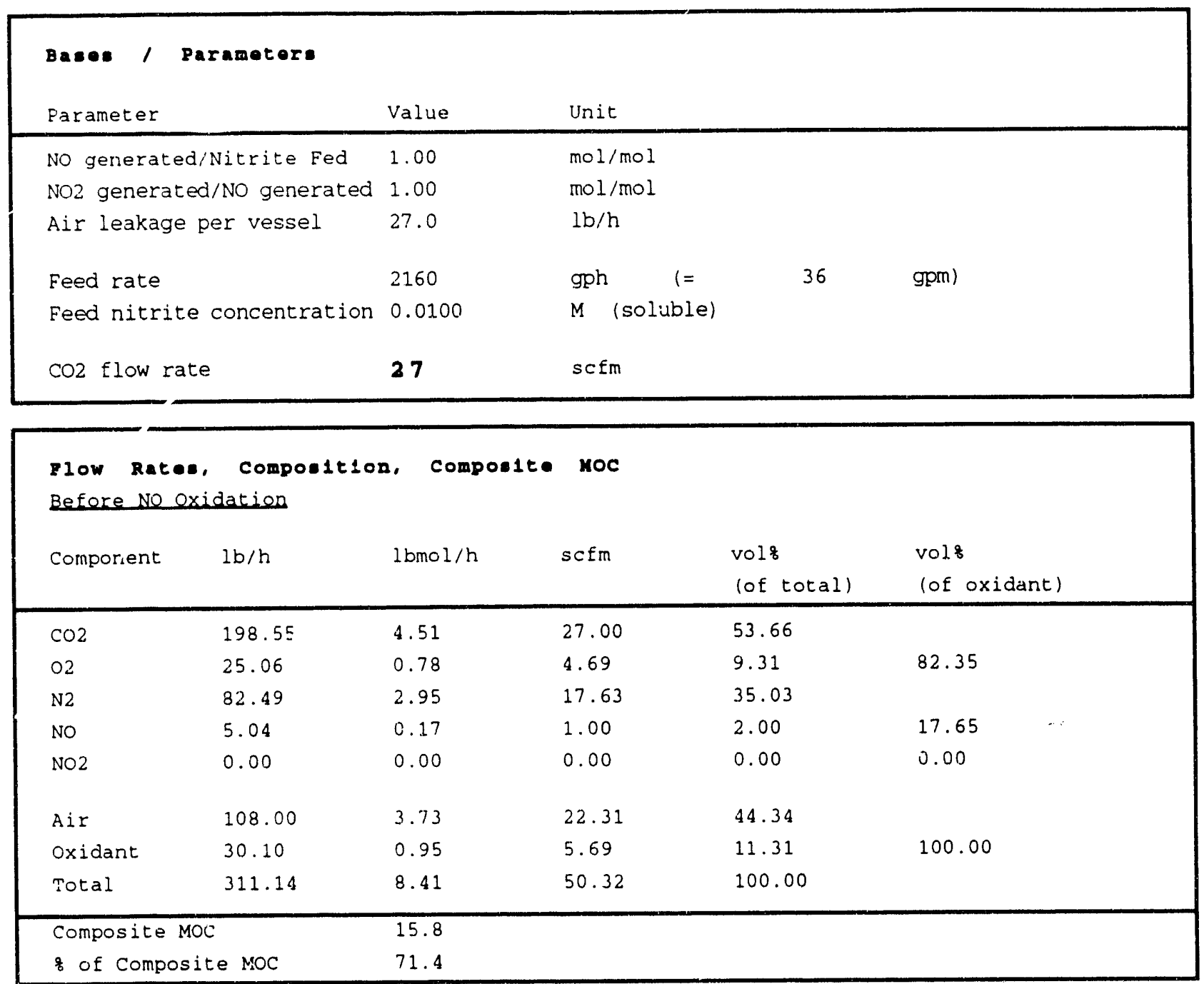

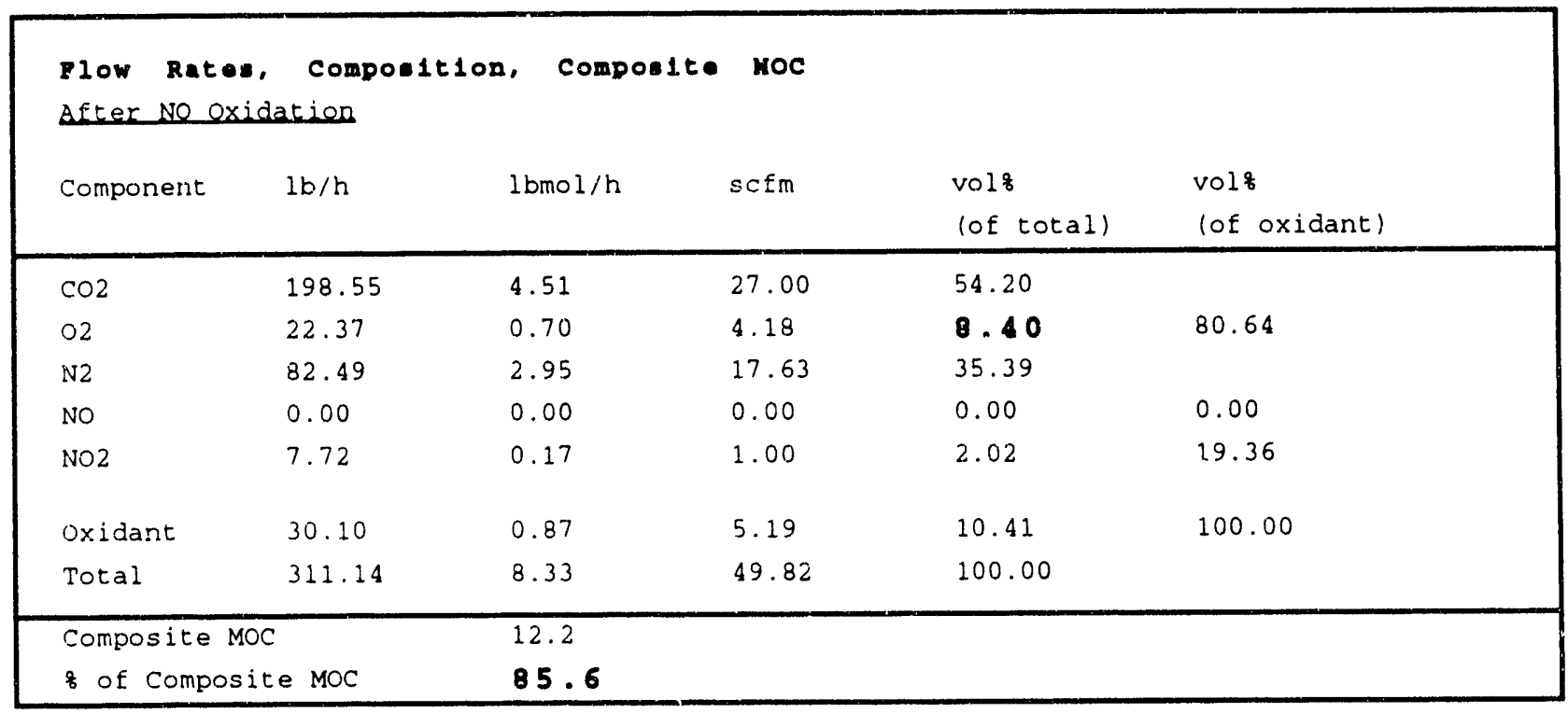


Table 70.33 No Generated/Nitrite Fed, High Air Inleakage

\begin{tabular}{|c|c|c|c|c|}
\hline $\begin{array}{l}\text { Bases , Parametere } \\
\text { Earameter }\end{array}$ & Value & Unit & & \\
\hline NO generated/Nitrite Eed & 0.33 & $\mathrm{~mol} / \mathrm{mol}$ & & \\
\hline NO2 generated/NO generated & 1.00 & $\mathrm{~mol} / \mathrm{mol}$ & & \\
\hline Air leakage per vessel & 23.5 & $1 b / h$ & & \\
\hline Feed rate & 2160 & gph & 36 & gpm) \\
\hline Feed nitrite concentration & 0.0100 & M (soluble) & & \\
\hline $\mathrm{CO} 2$ flow race & 27 & $\operatorname{scfm}$ & & \\
\hline
\end{tabular}

\begin{tabular}{|c|c|c|c|c|c|}
\hline $\begin{array}{l}\text { Plow Rat } \\
\text { Before No } \\
\text { Component }\end{array}$ & $\begin{array}{l}\text { Compo } \\
\text { dation } \\
1 \mathrm{~b} / 1 .\end{array}$ & $1 \mathrm{bmol} / \mathrm{h}$ & $\operatorname{scfm}$ & $\begin{array}{l}\text { volo } \\
\text { (of total) }\end{array}$ & \\
\hline $\mathrm{CO} 2$ & 198.55 & 4.51 & 27.00 & 57.75 & $\begin{array}{l}\text { vols } \\
\text { (of oxidant) }\end{array}$ \\
\hline 02 & 21.81 & 0.68 & 4.08 & 8.72 & 92.48 \\
\hline $\mathrm{N} 2$ & 71.80 & 2.56 & 15.34 & 32.82 & \\
\hline No & 1.66 & 0.06 & 0.33 & 0.11 & 7.52 \\
\hline NO2 & 0.00 & 0.00 & 0.00 & 0.00 & 0.00 \\
\hline Air & 94.00 & 3.25 & 19.42 & 41.54 & \\
\hline Oxidant & 23.47 & 0.74 & 4.41 & 9.43 & 100.00 \\
\hline Total & 293.82 & 7.81 & 46.75 & 100.00 & \\
\hline \multicolumn{2}{|c|}{ Composite MOC } & $\begin{array}{l}14.7 \\
64.3\end{array}$ & & & \\
\hline
\end{tabular}

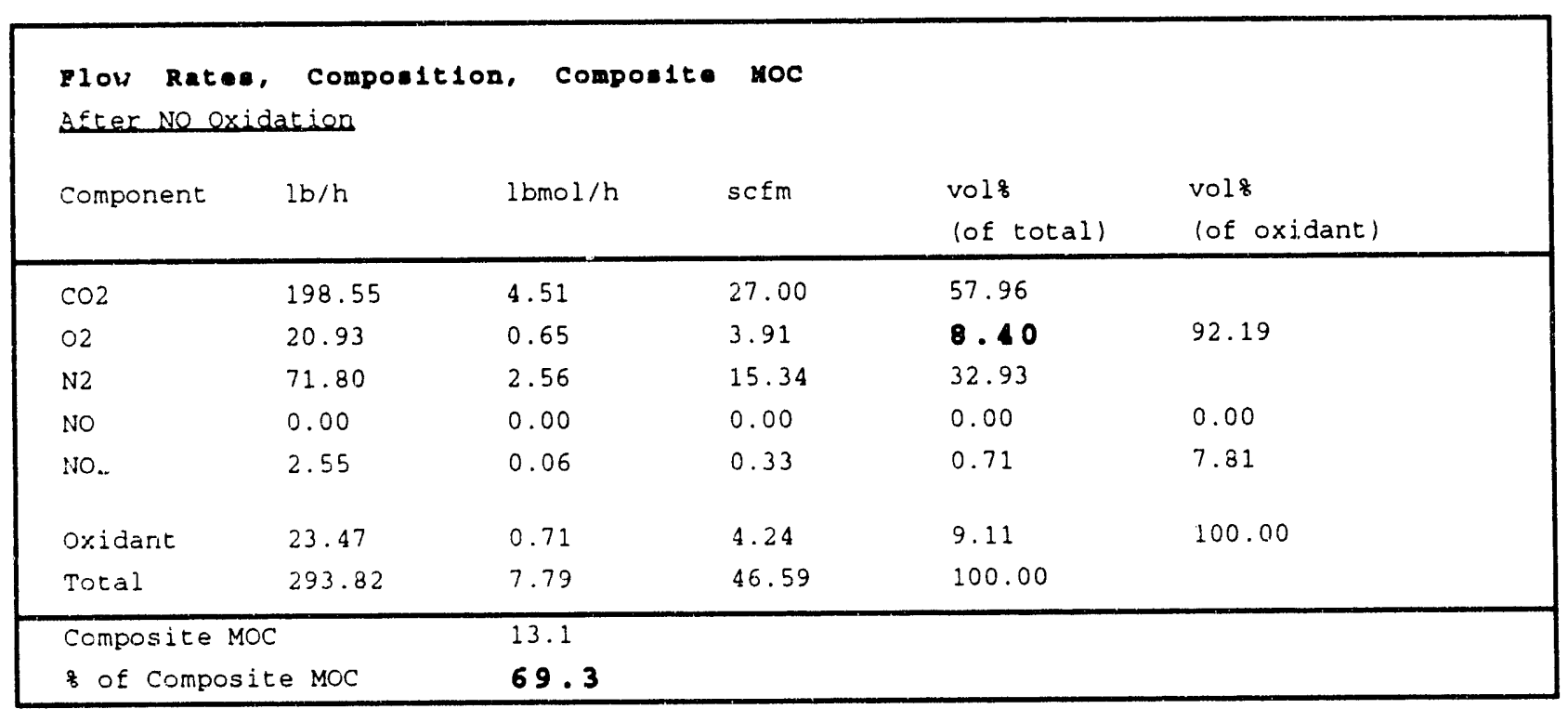


Table 80.33 No Gen./Nitrite Fed, Design Basis Air Inleakage

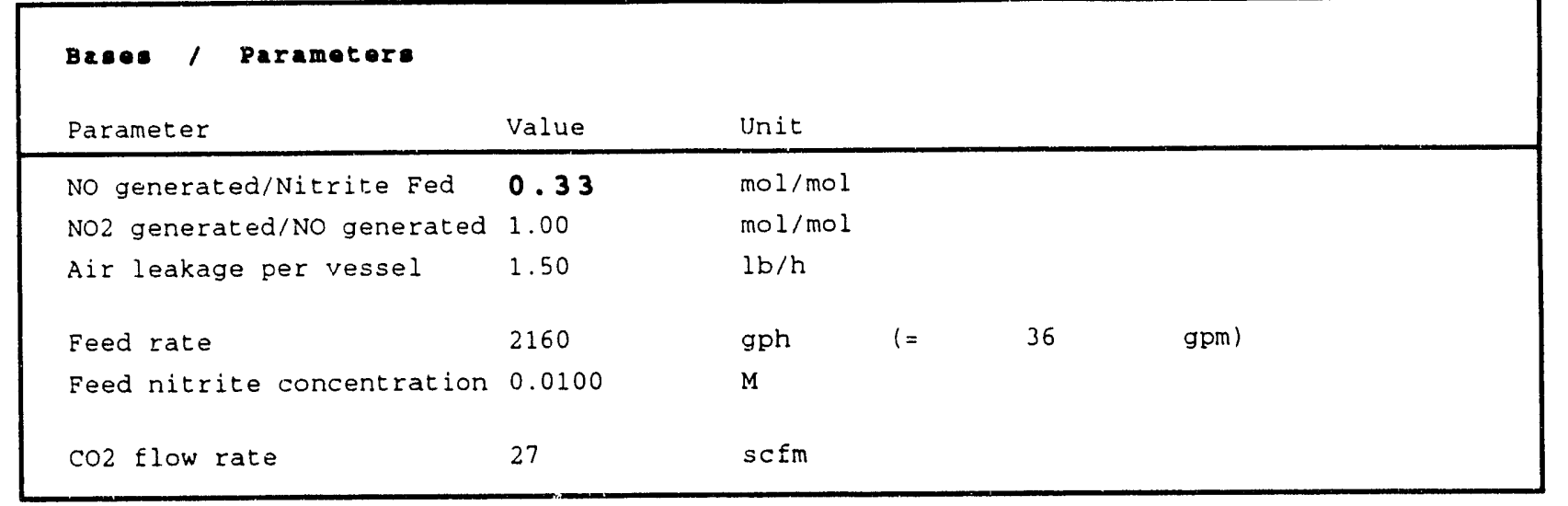

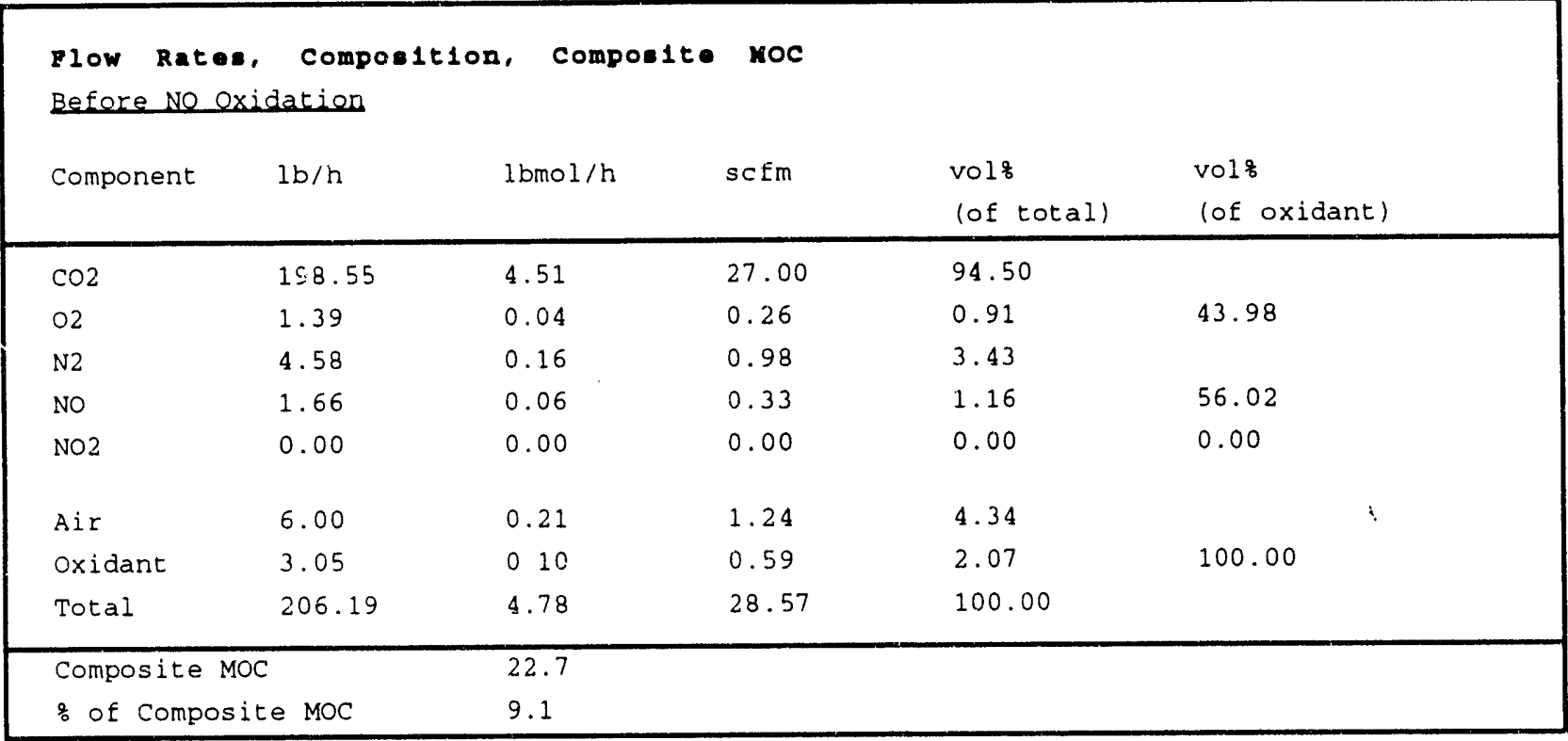

\begin{tabular}{|c|c|c|c|c|c|}
\hline \multicolumn{6}{|c|}{$\begin{array}{l}\text { Plow Rates, composttion, } \\
\text { After No Oxidation }\end{array}$} \\
\hline $\mathrm{CO} 2$ & 198.55 & 4.51 & 27.00 & 95.05 & \\
\hline 02 & 0.51 & 0.02 & 0.09 & 0.33 & 22.19 \\
\hline $\mathrm{N} 2$ & 4.58 & 0.16 & 0.98 & 3.45 & \\
\hline No & 0.00 & 0.00 & 0.00 & 0.00 & 0.60 \\
\hline $\mathrm{NO} 2$ & 2.55 & 0.06 & 0.33 & 1.17 & 77.81 \\
\hline Oxidant & 3.05 & 0.07 & 0.43 & 1.50 & 100.00 \\
\hline Total & $206 \quad 19$ & 4.75 & 28.41 & 100.00 & \\
\hline $\begin{array}{l}\text { Composite } \\
\% \text { of Comp }\end{array}$ & e MOC & $\begin{array}{l}8.8 \\
17.0\end{array}$ & & & \\
\hline
\end{tabular}


Table 9

PR Dilution strategy

For The Low Nitrite Precipitate Hydrolysis Process During DWPF Cold Chemical Runs During Feeding (And 15 Minutes After Feeding)

Maximum feed nitrite concentration

slurry feed rate

Carbon dioxide purge rate

Oxygen concentration
Target :

Maximum :

Target :

Minimum:

Maximum :
$0.01 \mathrm{M}$ (soluble)

$30 \mathrm{gpm}$

$36 \mathrm{gpm}$ (=1208 of target)

$34 \operatorname{scfm}$

27 scfm (=80\% of target)

8.4 volf 


\section{References}

1. J. P. Doherty, I. D. Goren, "Technical Data Summary for the Defense Waste Processing Facility Precipitate Hydrolysis Process (U)", DPST-84-98, July 11, 1985

2. M.A. Baich, R.A. Jacobs, J.C. Marek, J. Morrison, H.B. Shah, S.R. Young, "Defense Waste Processing Facility: Technical Bases For HAN Precipitate Hydrolysis Process. DWPF Integrated Cold Runs (U) ", WSRC-TM-90-11, December 1990.

3. R. A. Jacobs, "Benzene/Nitrous oxide Flammability in the Precipitate Hydrolysis Process (U)", DPST-89-348, September 18, 1989.

4. D.P. Lambert, R.E. Edwards, H.B. Shah, S.R. Young, "Run 60 Preliminary Report Precipitate Hydrolysis Experimental Facility (U)", WSRC-RP-92-943 Rev0, July 28, 1992.

5. NFPA 69: Standard on Explosion Prevention Systems, 1992 Edition, National Fire Protection Association, January 17, 1992.

6. R. A. Jacobs, "DWPF Precipitate Hydrolysis Process - High Air In Hydrolysis Process - High Air Leakage During N20 Generation (U) ", WSRC-TR-91-0158, April 4, 1991.

7. J. C. Marek, "Fin-1 Wash Precipitate Feed Simulants For DWPF Cold Chemical Runs (U)", WSRC-RP-92-703, May 15, 1992. 


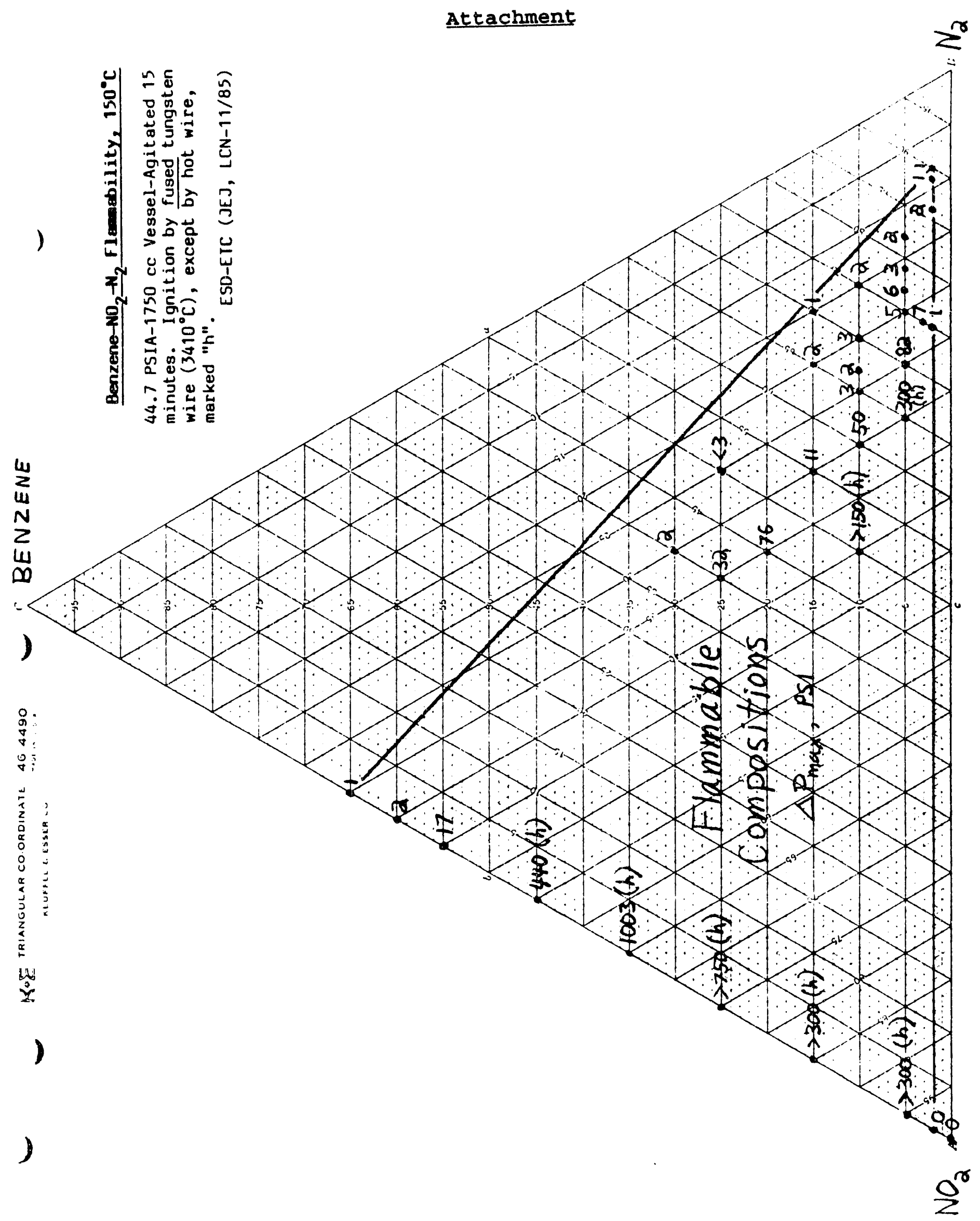




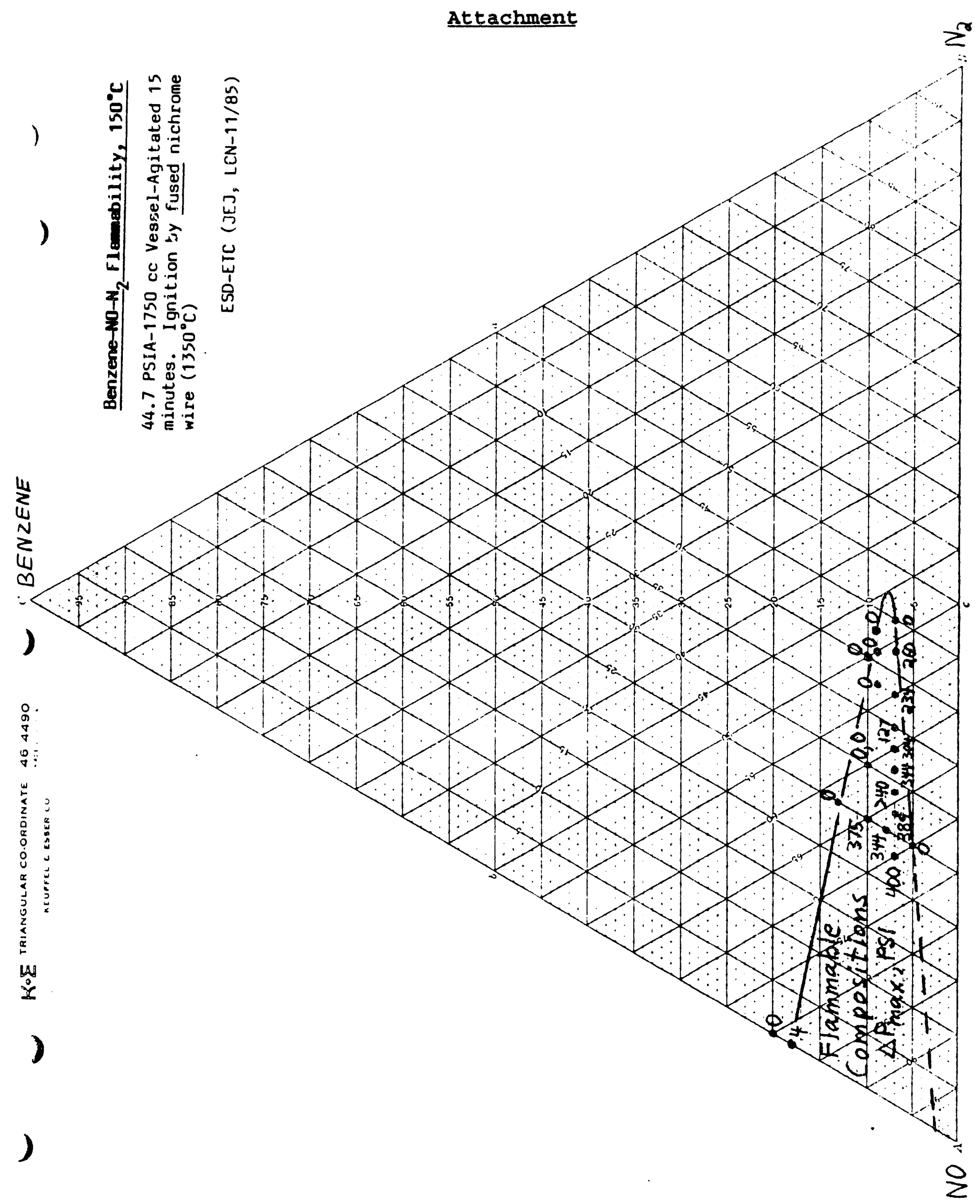




\section{SRTC Distribution:}

E. W. Holtzscheiter, 773-A

J. T. Carter, 704-1T

L. F. Landon, 704-T

C. T. Randall, 704-T

M. J. Plodinec, 773-A

R. E. Edwards, 704-1T

D. P. Lambert, 704-1T

H. B. Shah, 704-1T

S. R. Young, 704-1T

M. A. Baich, 704-T

R. E. Eibling, 704-T

R. A. Jacobs, 704-T

J. C. Marek, 704-T

C. J. Bannochie, 704-1T

A. S. Choi, 704-1T

SRTC Records (4) 

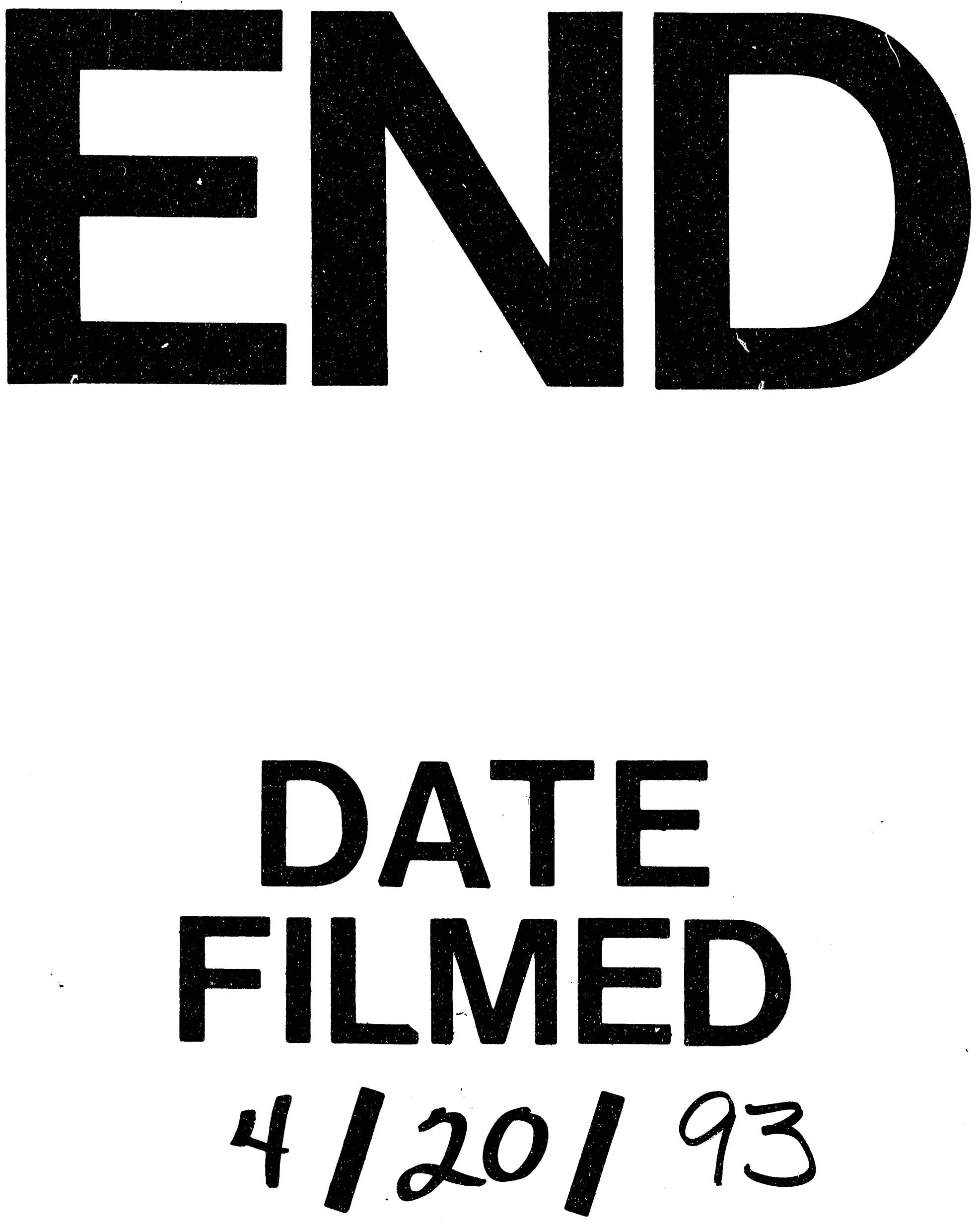
